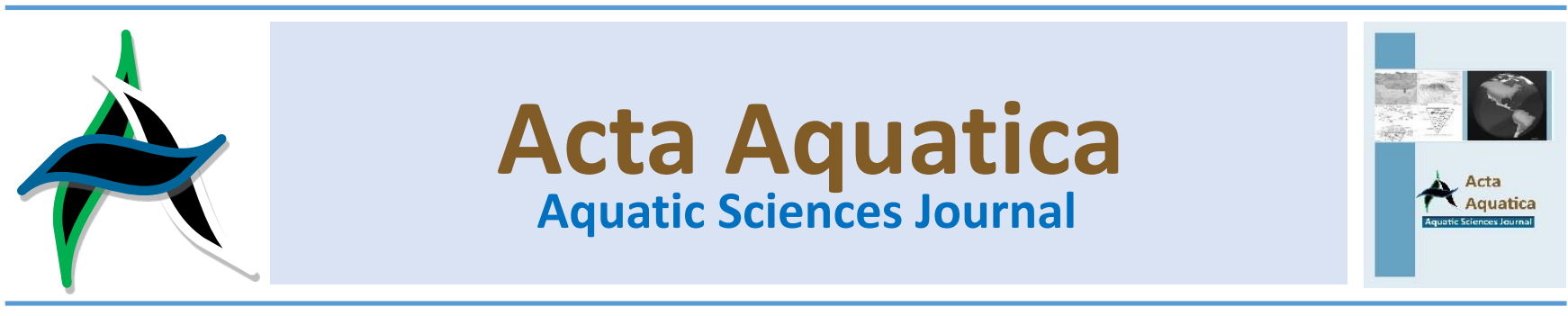

\title{
Pengaruh salinitas yang berbeda terhadap tingkat pertumbuhan dan kelangsungan hidup tiram (Crassostrea sp)
}

\section{The effect of different level of salinity on growth and survival rate of oyster (Crassostrea sp)}

\author{
Helmi Yanti ${ }^{\text {* }}$, Muliani ${ }^{\text {a }}$ dan Munawar Khalil ${ }^{b}$ \\ ${ }^{a}$ Program Studi Budidaya Perairan, Fakultas Pertanian, Universitas Malikussaleh \\ ${ }^{b}$ Program Studi Ilmu Kelautan, Fakultas Pertanian, Universitas Malikussaleh
}

\begin{abstract}
Abstrak
Tiram (Crassostrea sp) merupakan salah satu bivalvial potensial yang dapat dikembangkan dalam rangka meningkatkan pendapatan ekonomi. Kualitas air (salinitas) yang baik akan mempengaruhi pertumbuhan dan kelangsungan hidup tiram. Penelitian ini bertujuan untuk mengetahui pengaruh salinitas yang berbeda (30 ppt, 25 ppt, 20 ppt, 15 ppt) terhadap tingkat pertumbuhan dan kelangsungan hidup tiram (Crassostrea sp). Penelitian ini dilaksanakan di Laboratorium Hatchery dan Teknologi Reulet Program Studi Budidaya Perairan Fakultas Pertanian Universitas Malikussaleh dari bulan April sampai Juni 2015. Adapun perlakuannya yaitu benih tiram dipelihara pada salinitas 30 ppt, 25 ppt, 20 ppt, dan 15 ppt. adapun rancangan yang digunakan pada penelitian ini adalah Rancangan Acak Lengkap (RAL) dengan 3 ulangan dan 4 perlakuan dan dilanjutkan dengan uji Beda Nyata Terkecil (BNT) jika terdapat perbedaan. Parameter yang diamati adalah kelangsungan hidup, pertambahan panjang, lebar, pertambahan bobot dan kualitas air. Pertambahan bobot, lebar, dan panjang tertinggi terdapat pada perlakuan A yaitu dengan nilai rata-rata sebesar 1,104 gram, 0,144 $\mathrm{mm}, 0,252 \mathrm{~mm}$ dan pertambahan bobot, lebar, dan panjang terendah terdapat pada perlakuan $D$ yaitu 0,358 gram, $0,039 \mathrm{~mm}$ dan 0,063 mm. Rata-rata kelangsungan hidup yaitu 97\% pada perlakuan A, 93\% pada perlakuan B dan 90\% pada perlakuan $C$ dan $D$. parameter kualitas air berada pada kisaran yang baik untuk pertumbuhan tiram dalam kisaran suhu 27,3$30,1^{\circ} \mathrm{C}, \mathrm{pH} \mathrm{7,2-7,8}$, dan DO 4,6-6,0 ppm.
\end{abstract}

Kata kunci: bivalvia; tiram; salinitas; pertumbuhan; kelangsungan hidup

\begin{abstract}
Oyster (Crassostrea $\mathrm{sp}$ ) is one bivalvial potential that can be developed in order to improve the economic income. Water quality (salinity) which either will affect the growth and survival of oysters. This study aims to determine the effect of different salinity (30 ppt, $25 \mathrm{ppt}, 20 \mathrm{ppt}, 15 \mathrm{ppt}$ ) the growth rate and survival of oysters (Crassostrea sp). This research was conducted at Hatchery and Technology Laboratory, Aquaculture Department, Agriculture Faculty Malikussaleh University, which was held on April to June 2015. The treatment of seed oysters are reared at a salinity of $30 \mathrm{ppt}, 25 \mathrm{ppt}, 20 \mathrm{ppt}$ and $15 \mathrm{ppt}$. As for the design used in this study is completely randomized design (CRD) with three replications and 4 treatments and continued by Least Significant Difference (LSD) if there is a difference. Parameters measured were survival, the length, width, weight gain and water quality. Added weight, width, and length highest in treatment $A$ is the average value of 1,104 gram, $0,144 \mathrm{~mm}$, $0,252 \mathrm{~mm}$, and weight gain, width, and length was lowest for the treatment $D$, namely $0.358 \mathrm{~g}, 0.039 \mathrm{~mm}$ and $0,063 \mathrm{~mm}$. The average survival is $97 \%$ at treatment $A, 93 \%$ in treatment $B$ and $90 \%$ in treatment $C$ and $D$. The water quality parameters in the range which is good for the growth of oysters in the temperature range from $27,3-30,1^{\circ} \mathrm{C}, \mathrm{pH} 7,2$ to 7,8 , and $\mathrm{DO} 4,6$ to $6,0 \mathrm{ppm}$.
\end{abstract}

Keywords: bivalvia; oyster; salinity; growth; survival rate

\footnotetext{
* Korespondensi: Program Studi Budidaya Perairan, Fakultas Pertanian, Universitas Malikussaleh. Kampus utama Reuleut, Kec. Muara Batu Kabupaten Aceh Utara, Provinsi Aceh, Indonesia.

Tel: +62-645-41373 Fax: +62-645-59089.

e-mail: helmiyanti06@gmail.com
}

\section{Pendahuluan}

Bivalvia meliputi kerang, tiram, remis dan sebagainya. Tubuhnya berbentuk lateral compresses (pipih pada salah satu sisi), dan tubuh moluska tertutup oleh cangkang yang berasal dari sekretnya sendiri dengan dua bagian yang disebut valves. Bivalvia tidak mempunyai kepala dan radula (Castro \& Huber, 2007). Salah satu jenis bivalvia potensial yang dapat 
dikembangkan dalam rangka meningkatkan pendapatan ekonomi adalah dari jenis tiram. Saat ini budidaya tiram belum dikenal secara luas, umumnya masyarakat nelayan memanen atau mengumpulkan tiram dari alam untuk konsumsi sendiri dan sebagian lainnya untuk dijual. Di indonesia usaha budidaya tiram belum banyak dilakukan (Sudradjat, 1982).

Produksi tiram Indonesia untuk kebutuhan ekspor belum banyak memberikan sumbangan berarti bagi peningkatan devisa Negara. Volume ekspor tiram Indonesia pada tahun 2002 baru mencapai $304.873 \mathrm{~kg}$. Negara tujuan ekspor tiram Indonesia adalah Jepang, China, Singapura, Malaysia, Vietnam, Afrika Selatan, Australia, USA, Kanada, Inggris, Prancis, Jerman, Swiss, dan Polandia (Winanto, 2004).

Tiram termasuk salah satu jenis bivalvia yang mengalami permintaan pasar yang cukup tinggi, namun penyediaannya masih terbatas dikarenakan biota masih banyak yang ditangkap dari alam. Ada beberapa faktor yang menjadi masalah dalam kegiatan budidaya tiram, diantaranya yaitu pertumbuhannya yang lambat dan tingkat kematian yang tinggi. Upaya peningkatan produksi tiram dapat ditempuh dengan pengembangan usaha budidaya. Salah satu aspek penting dalam usaha budidaya adalah ketersediaan benih yang terjamin kualitas dan kuantitasnya. Dalam usaha budidaya tiram didukung oleh banyak faktor yang mempengaruhi pertumbuhan dan kelangsungan hidup tiram diantaranya kualitas air seperti salinitas, $\mathrm{pH}$, suhu. Salinitas merupakan salah satu parameter lingkungan yang mempengaruhi proses biologi dan secara langsung akan mempengaruhi kehidupan organisme antara lain yaitu jumlah makanan yang dikonsumsi, nilai konversi makanan, dan daya kelangsungan hidupSalinitas merupakan salah satu parameter penting dalam kegiatan budidaya untuk pertumbuhan dan kelangsungan hidup tiram. Namun belum diketahui salinitas yang tepat untuk pertumbuhan tiram pada media budidaya. Maka oleh karena itu peneliti tertarik untuk melakukan penelitian pengaruh salinitas yang berbeda terhadap tingkat pertumbuhan dan kelangsungan hidup tiram (Crassostrea sp).

\section{Bahan dan metode}

\subsection{Waktu dan tempat}

Penelitian ini dilaksanakan pada tanggal 15 April - 13 Juni 2015 yang berlokasi di Laboratorium Hatchery dan Teknologi Reulet Program Studi Budidaya Perairan Fakultas Pertanian Universitas Malikussaleh.

\subsection{Bahan dan alat}

Bahan yang digunakan dalam penelitian ini berupa air laut, air tawar, fitoplankton dan spat tiram 120 dengan populasi 10 ekor pada setiap wadah dan pakan yang diberikan berupa fitoplankton. Adapun alat yang digunakan pada penelitian ini adalah refraktometer, termometer, vernier caliper, DO meter, $\mathrm{pH}$ meter, timbangan analitik, aerator, alat sifon, planktonet, deterjen, alat tulis dan akuarium dengan ukuran $30 \times 20 \times 20 \mathrm{~cm}$.

\subsection{Metode penelitian}

Metode penelitian yang digunakan adalah metode eksperimen dengan menggunakan berbagai jenis salinitas yang berbeda pada setiap perlakuan. Rancangan penelitian yang digunakan adalah Rancangan Acak Lengkap (RAL) non faktorial dengan 4 perlakuan dan 3 ulangan. Perlakuan yang digunakan adalah sebagai berikut:
Perlakuan $\mathrm{A}=$ benih tiram dipelihara pada salinitas $30 \mathrm{ppt}$ Perlakuan $B=$ benih tiram dipelihara pada salinitas $25 \mathrm{ppt}$ Perlakuan $C=$ benih tiram dipelihara pada salinitas $20 \mathrm{ppt}$ Perlakuan $\mathrm{D}=$ benih tiram dipelihara pada salinitas $15 \mathrm{ppt}$

\subsection{Prosedur penelitian}

\subsubsection{Persiapan wadah dan air media}

Wadah percobaan yang digunakan pada penelitian ini berupa akuarium yang berukuran $30 \times 20 \times 20 \mathrm{~cm}$ sebanyak 12 buah yang dicuci bersih dengan menggunakan deterjen kemudian dikeringkan dan dibiarkan selama 24 jam, selanjutnya diisi air setinggi $9,5 \mathrm{~cm}$ dan dipasang aerasi. Sebelum penelitian ini dilakukan, semua alat yang digunakan dalam penelitian harus disterilkan terlebih dahulu agar bersih dan bebas dari kontaminasi.

Air yang digunakan dalam penelitian ini adalah air laut yang bersalinitas 32 ppt dan air tawar. Untuk mendapatkan salinitas sesuai dengan perlakuan yang diinginkan, maka dilakukan pengenceran dengan menggunakan persamaan (Keenan, 1999) yaitu:

Keterangan :

$$
V_{1} \cdot M_{1}=V_{2} \cdot M_{2}
$$

$\mathrm{V} 1$ = volume air sebelum pengenceran (L)

M1 = salinitas awal (ppt)

V2 = volume air setelah pengenceran (L)

$\mathrm{M} 2$ = salinitas air setelah pengenceran (ppt)

\subsubsection{Introduksi tiram ke media perlakuan}

Tiram uji yang digunakan dalam penelitian ini adalah tiram yang diperoleh dari Loskala. Tiram ditebar dalam 12 wadah akuarium dengan kepadatan 10 tiram/wadah. Berat awal 3-7 gram dan panjang awal 23-36 mm.

\subsubsection{Aklimatisasi dan pemberian pakan}

Tiram yang telah disiapkan untuk penelitian akan diaklimatisasi dulu selama 2 hari yang bertujuan untuk penyesuaian lingkungan. Selama masa aklimatisasi tiram tetap diberi pakan, pemberian pakan sebanyak 1 liter/wadah yaitu 3 kali sehari (pukul 07.00 wib, 12.00 wib, dan pada pukul 17.00 wib). Pakan yang diberikan berupa fitoplankton yang di kultur secara alami.

\subsubsection{Kultur pakan alami (fitoplankton)}

Dalam pengkulturan fitoplankton diperlukan selang aerasi dan wadah yang berukuran 60 liter yang diisi dengan air laut, kemudian saring air media dengan saringan berukuran 15 mikron selanjutnya dilakukan sterilisasi. Bibit fitoplankton diambil di alam dengan menggunakan planktonet selanjutnya dituangkan kedalam wadah dan dilakukan pengkulturan, selanjutnya dalam pemeliharaan pakan alami (fitoplankton) diberikan pupuk walne teknis $1 \mathrm{ml} / \mathrm{l}$. Tujuannya untuk membantu memenuhi kebutuhan nutrisi bagi pertumbuhan fitoplankton. Pupuk teknis ini meliputi NPK, UREA, dan TSP.

\subsection{Parameter uji}

Parameter yang diamati dalam pelaksanaan kegiatan penelitian ini adalah sebagai berikut: 


\subsubsection{Panjang dan lebar cangkang}

Pertumbuhan panjang dan lebar cangkang diukur setiap 10 hari sekali. Panjang cangkang tiram di ukur dari dorsalis ke ventralis dan lebar diukur dari posterior ke posterior dengan menggunakan vernier caliper, rumus pengukuran panjang dan lebar menurut Effendie (1979) yaitu:

$$
\mathrm{P}=\mathrm{Pt}-\mathrm{Po} \quad \mathrm{L}=\mathrm{Lt}-\mathrm{LO}
$$

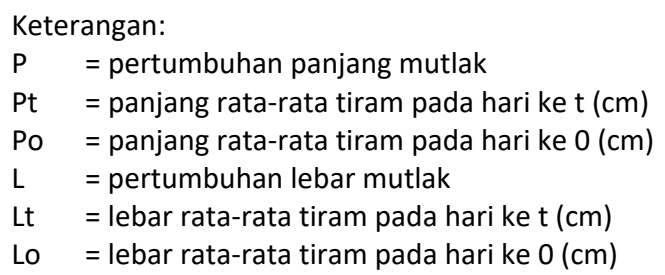

\subsubsection{Pertumbuhan bobot keseluruhan tiram}

Pertumbuhan bobot tiram ditimbang setiap 10 hari sekali total keseluruhan tiram dengan menggunakan timbangan, rumus pengukuran bobot menurut Effendie (1979) yaitu :

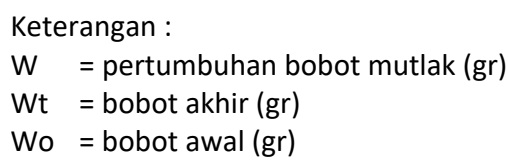

\subsubsection{Kelangsungan hidup}

Pengamatan jumlah tiram yang hidup diukur pada awal dan akhir penelitian dengan cara menghitung seluruh jumlah tiram yang masih hidup yaitu dengan menggunakan rumus Effendi (1979):

\section{$\mathrm{SR}=\mathrm{Nt} / \mathrm{No} \times 100 \%$}

Keterangan:

$\mathrm{SR} \quad=$ tingkat kelangsungan hidup (\%)

$\mathrm{Nt}=$ jumlah tiram yang hidup pada akhir penelitian (ekor)

No = jumlah tiram yang hidup pada awal penelitian (ekor)

\subsubsection{Kualitas air}

Pengukuran kualitas air dilakukan sekali sehari sedangkan penyifonan dilakukan 3 hari sekali. Parameter yang diukur adalah $\mathrm{pH}$, suhu, dan oksigen telarut (DO).

\subsection{Analisis data}

Data yang digunakan dalam penelitian ini yaitu menggunakan Rancangan Acak Lengkap (RAL) non faktorial dengan 4 perlakuan dan 3 kali ulangan, (Yitnosumarto, 1990), dengan persamaan :

\section{Keterangan :}

$$
Y_{i j}==\mu+\alpha i+\varepsilon i j
$$

$\mathrm{Yij}_{\mathrm{ij}}=$ variabel yang diamati pada pertumbuhan tiram pada perlakuan ke-i $(i=A, B, C, D)$ dan ulangan ke-j $(j=1,2,3)$

$\mu=$ rata-rata umum

$\alpha \mathrm{i}=1,2,3$ (ulangan)

हij $=$ kesalahan/ Galat

Data hasil penelitian di sajikan dalam bentuk tabel dan grafik kemudian dianalisis dengan analysis of variance (ANOVA) dengan menggunakan software excel. Apabila terdapat perlakuan yang berbeda nyata $\left(F_{\text {hitung }}>F_{\text {tabel }}\right)$ maka selanjutnya dilakukan uji lanjut dengan menggunakan uji BNT (Beda Nyata Terkecil) sedangkan data kualitas air dianalisis secara deskriptif.

\section{Hasil dan pembahasan}

\subsection{Hasil}

\subsubsection{Kelangsungan hidup (survival rate)}

Hasil penelitian menunjukkan bahwa salinitas yang berbeda memberi pengaruh terhadap kelangsungan hidup tiram (Crassostrea sp). Rata-rata tingkat kelangsungan hidup tiram (Crassostrea sp) dapat dilihat pada gambar 1.

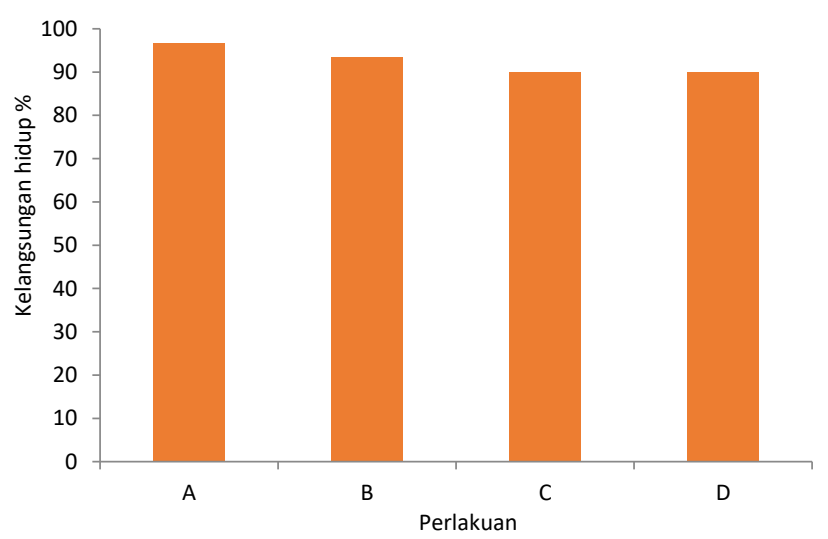

Gambar 1. Tingkat kelangsungan hidup tiram (Crassostrea sp).

Keterangan:

$A=$ benih tiram dipelihara pada salinitas $30 \mathrm{ppt}$

$\mathrm{B}=$ benih tiram dipelihara pada salinitas $25 \mathrm{ppt}$

$\mathrm{C}=$ benih tiram dipelihara pada salinitas $20 \mathrm{ppt}$

$\mathrm{D}=$ benih tiram dipelihara pada salinitas $15 \mathrm{ppt}$

Tingkat kelangsungan hidup (SR) tiram (Crassostrea sp) setelah dilakukan penelitian dengan salinitas yang berbeda menunjukkan perbedaan pada tiap perlakuan. Tingkat persentase yang tertinggi dijumpai pada perlakuan A yaitu $97 \%$, disusul dengan perlakuan $B$ yaitu $93 \%$, kemudian yang terendah pada perlakuan C yaitu $90 \%$ dan perlakuan D yaitu $90 \%$.

\subsubsection{Pertambahan panjang dan lebar tiram}

Hasil penelitian menunjukan bahwa salinitas yang berbeda menunjukkan hasil yang berbeda terhadap pertambahan panjang tiram (Crassostrea sp). Rata-rata pertambahan panjang tiram (Crassostrea sp) setiap sepuluh hari untuk masing-masing perlakuan dapat dilihat pada Gambar 2.

Rata-rata pertambahan panjang tertinggi terdapat pada perlakuan A yaitu sebesar 0,252 $\pm 0,08 \mathrm{~mm}$ selanjutnya perlakuan B yaitu sebesar 0,198 $\pm 0,07 \mathrm{~mm}$, kemudian pada perlakuan $C$ yaitu sebesar $0,125 \pm 0,06 \mathrm{~mm}$, sedangkan pertambahan panjang terendah terdapat pada perlakuan $D$ yaitu sebesar 0,063 $\pm 0,06 \mathrm{~mm}$.

Analisis statistik dengan uji Anova menunjukkan bahwa salinitas yang berbeda yaitu 30 ppt, 25 ppt, 20 ppt, dan 15 ppt, menunjukkan hasil berbeda sangat nyata terhadap pertambahan panjang tiram (Crassostrea sp), dengan nilai Fhitung $(65,00)$. Uji lanjut (BNT) memperoleh hasil bahwa pada setiap perlakuan yang berbeda nyata terdapat antar perlakuan A dengan perlakuan $C$ dan perlakuan $D$, dan perlakuan $B$ dengan perlakuan D. 


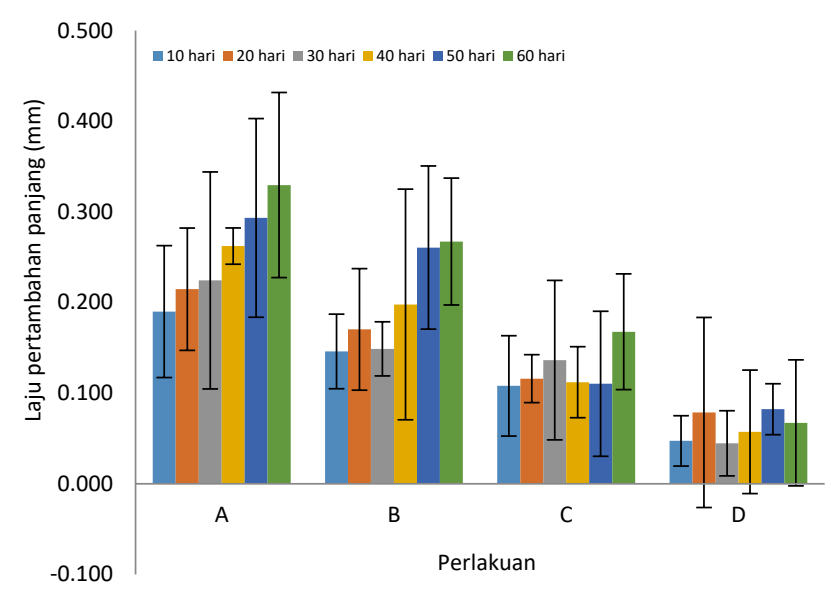

Gambar 2. Pertambahan panjang tiram (Crassostrea sp).

Keterangan:

$A=$ benih tiram dipelihara pada salinitas $30 \mathrm{ppt}$

$\mathrm{B}=$ benih tiram dipelihara pada salinitas $25 \mathrm{ppt}$

$\mathrm{C}=$ benih tiram dipelihara pada salinitas $20 \mathrm{ppt}$

$\mathrm{D}=$ benih tiram dipelihara pada salinitas $15 \mathrm{ppt}$

Rata-rata pertambahan lebar tiram (Crassostrea sp) setiap sepuluh hari untuk masing-masing perlakuan dapat dilihat pada Gambar 3.

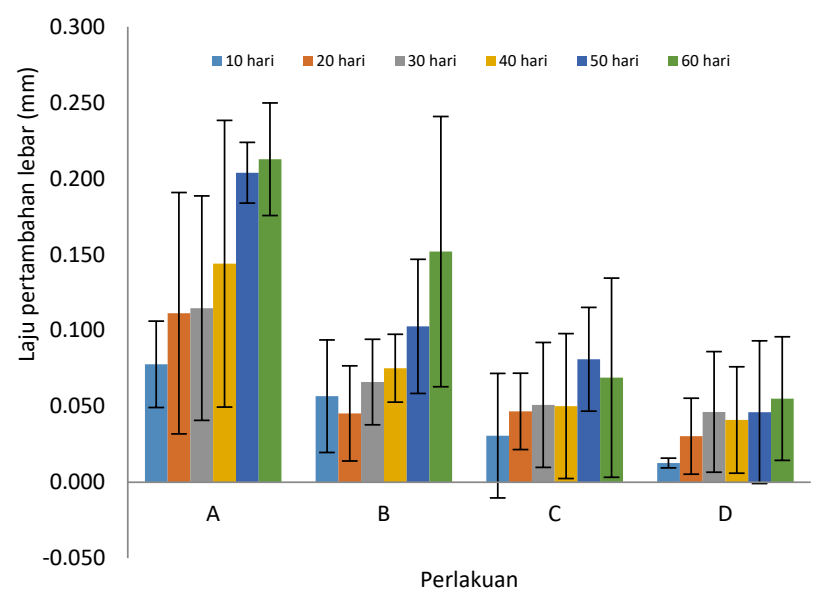

Gambar 3. Laju pertambahan lebar tiram (Crassostrea sp).

Keterangan:

A $=$ benih tiram dipelihara pada salinitas $30 \mathrm{ppt}$

$\mathrm{B}=$ benih tiram dipelihara pada salinitas $25 \mathrm{ppt}$

$\mathrm{C}=$ benih tiram dipelihara pada salinitas $20 \mathrm{ppt}$

$\mathrm{D}=$ benih tiram dipelihara pada salinitas $15 \mathrm{ppt}$

Rata-rata pertambahan lebar tiram yang tertinggi terdapat pada perlakuan $A$ yaitu sebesar $0,144 \pm 0,06 \mathrm{~mm}$, untuk perlakuan $B$ yaitu sebesar $0,083 \pm 0,04 \mathrm{~mm}$, perlakuan $C$ yaitu sebesar 0,055 $\pm 0,04 \mathrm{~mm}$, sedangkan pertambahan panjang terendah terdapat pada perlakuan $D$ yaitu sebesar $0,039 \pm 0,03$ $\mathrm{mm}$.

Berdasarkan analisis statistik dengan uji $\mathrm{F}$ menunjukkan bahwa salinitas yang berbeda yaitu 30 ppt, 25 ppt, 20 ppt, dan 15 ppt, menunjukkan hasil berbeda sangat nyata terhadap pertambahan lebar tiram (Crassostrea sp), dengan nilai $F_{\text {hitung }}(42,00)$. Dari hasil uji lanjut (BNT) memperoleh hasil bahwa pada setiap perlakuan berpengaruh antar perlakuan dan pertambahan lebar yang terbaik juga pada perlakuan $\mathrm{A}$.

\subsubsection{Pertambahan bobot}

Salinitas yang berbeda menunjukkan hasil rata-rata yang berbeda terhadap pertambahan bobot tiram (Crassostrea sp). Rata-rata pertambahan bobot tiram (Crassostrea sp) setiap sepuluh hari disajikan pada Gambar 4 di bawah ini.

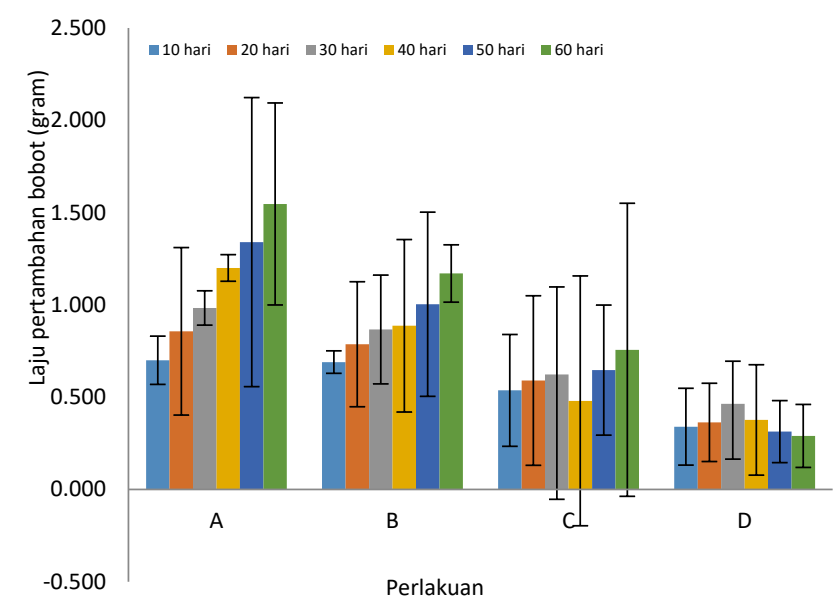

Gambar 4. Pertambahan bobot tiram (Crassostrea sp).

Keterangan:

$\mathrm{A}=$ benih tiram dipelihara pada salinitas $30 \mathrm{ppt}$

$\mathrm{B}=$ benih tiram dipelihara pada salinitas $25 \mathrm{ppt}$

$\mathrm{C}=$ benih tiram dipelihara pada salinitas $20 \mathrm{ppt}$

$\mathrm{D}=$ benih tiram dipelihara pada salinitas $15 \mathrm{ppt}$

Rata-rata pertambahan bobot tiram tertinggi terdapat pada perlakuan A yaitu sebesar 1,104 $\pm 0,35$ gram, kemudian pada perlakuan $B$ yaitu sebesar $0,901 \pm 0,30$ gram, selanjutnya pada perlakuan $C$ sebesar $0,606 \pm 0,51$ gram, sedangkan pertambahan bobot yang terendah terdapat pada perlakuan $D$ yaitu sebesar $0,358 \pm 0,21$ gram.

Untuk analisis statistik dengan uji $\mathrm{F}$ menunjukkan hasil berbeda sangat nyata terhadap pertambahan bobot tiram (Crassostrea $\mathrm{sp}$ ) dengan nilai $\mathrm{F}_{\text {hitung }}(38,00)$. Dari hasil uji lanjut (BNT) memperoleh hasil bahwa pada setiap perlakuan yang berbeda nyata terdapat antar perlakuan A dengan perlakuan $C$ dan $D$ dan perlakuan $B$ dengan perlakuan $D$.

\subsubsection{Parameter kualitas air}

Parameter fisika kimia air yang diamati dalam penelitian ini selama 60 hari meliputi suhu, pH, dan DO sedangkan salinitas ditentukan sesuai dengan masing-masing perlakuan (Gambar 5)
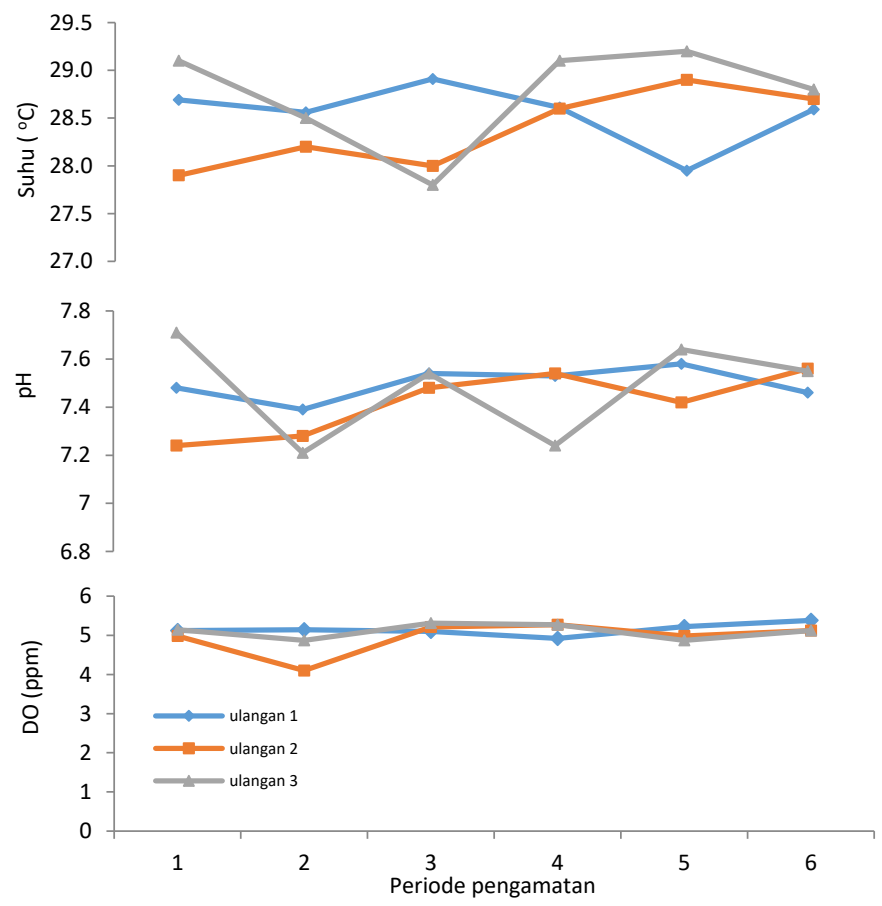

Gambar 5. Data pengamatan suhu, pH, dan DO selama penelitian. 
Hasil pengamatan kisaran perubahan kualitas air pada media pemeliharaan selama penelitian dapat dilihat pada Tabel 1 di bawah ini.

Tabel 1.

Data kualitas air selama penelitian

\begin{tabular}{lccc}
\hline \multicolumn{1}{c}{ Parameter } & Hasil pengamatan & Rata-rata & Standar deviasi \\
\hline Suhu & $27,3-30,1^{\circ} \mathrm{C}$ & $28,6^{\circ} \mathrm{C}$ & 0,63 \\
pH & $7,2-7,8$ & 7,5 & 0,13 \\
DO & $4,6-6,0 \mathrm{ppm}$ & $5,1 \mathrm{ppm}$ & 0,32 \\
\hline
\end{tabular}

\subsection{Pembahasan}

\subsubsection{Hubungan salinitas dengan tingkat kelangsungan hidup (survival rate) tiram}

Tinggi dan rendahnya nilai rata-rata kelangsungan hidup tiram pada semua perlakuan, ini disebabkan karena didukung oleh tersedianya pakan yang cukup sesuai dengan kebutuhan serta dilakukan pengontrolan kualitas air yang baik yaitu adanya penyiponan sisa pakan dan feses serta adanya pergantian air, dan dalam penyeleksian awal benih tiram yang digunakan adalah benih tiram yang sehat. Hal ini sesuai dengan pendapat Effendie (1979) yang menyatakan bahwa kelangsungan hidup tiram (Crassostrea sp) sangat ditentukan oleh tersedianya makanan yang baik serta pengelolaan kualitas air yang baik.

Tingkat persentase kelangsungan hidup tertinggi terdapat pada perlakuan A yaitu sebesar $97 \%$ ini disebabkan pada salinitas $30 \mathrm{ppt}$ tidak berpengaruh terhadap kelangsungan hidup tiram karena berada pada kisaran yang optimal untuk pertumbuhan tiram dan tidak menghambat terjadinya proses osmoregulasi dalam tubuhnya. Tingkat persentase terendah terdapat pada perlakuan $C$ dan $D$ yaitu $90 \%$ ini disebabkan pada salinitas 20 ppt dan 15 ppt berada pada kisaran yang optimal tetapi terjadinya penghambatan dalam proses osmoregulasi yang akan berdampak pada pemanfaatan energi yang lebih besar sehingga mengganggu pertumbuhan dan kelangsungan hidup tiram. Salinitas merupakan salah satu faktor fisiologis yang berpengaruh terhadap pemanfaatan pakan dan pertumbuhan bivalvia (Anggoro et al., 2012).

Apabila terjadi penurunan salinitas secara mendadak dalam kisaran yang cukup besar, maka akan menyulitkan tiram dalam pengaturan osmoregulasi tubuhnya sehingga dapat menyebabkan kematian. Pada penelitian ini salinitas yang ditentukan berada pada kisaran optimal untuk pertumbuhan tiram yaitu $15-30 \mathrm{ppt}$, maka tidak berpengaruh terhadap tingkat kelangsungan hidup. Menurut Anggoro et al. (2012) menyatakan bahwa pertumbuhan akan terjadi setelah organisme air mampu melakukan sistem homeostasis dan mempertahankan keadaan internal supaya tetap stabil sehingga memungkinkan tetap terselenggaranya aktivitas fisiologi di dalam tubuh.

\subsubsection{Hubungan salinitas dengan pertumbuhan tiram}

Perlakuan A (salinitas $30 \mathrm{ppt)}$ menunjukkan hasil pertambahan panjang yang tertinggi dengan nilai rata-rata yaitu $0,252 \mathrm{~mm}$. ini disebabkan karena salinitas $30 \mathrm{ppt}$ sesuai dengan habitat aslinya sehingga tidak menyebabkan hilangnya nafsu makan, selain itu juga pakan yang diberikan memiliki gizi yang seimbang dan kandungan nutrisi yang sesuai untuk kebutuhan pertumbuhan tiram (Crassostrea $\mathrm{sp}$ ), sehingga pertambahan panjang pada perlakuan ini lebih tinggi dibandingkan pertambahan panjang pada perlakuan lain.

Menurut Gosling (2003), pertumbuhan pada bivalvia dipengaruhi oleh banyak faktor, yaitu faktor lingkungan dan suplai makanan. Tanpa adanya suplai makanan maka tidak akan terjadi proses pertumbuhan yang baik. Bivalvia akan memberikan respon terhadap perubahan salinitas dengan cara menutup cangkangnya dan menyesuaikan konsentrasi ion, asam amino dan molekul lainnya untuk menjaga kestabilan volume sel.

Pertambahan panjang terendah terdapat pada perlakuan D (salinitas $15 \mathrm{ppt}$ ) yaitu $0,063 \mathrm{~mm}$. Rendahnya pertambahan panjang pada perlakuan D disebabkan karena salinitas $15 \mathrm{ppt}$ tidak sesuai dengan kehidupannya, yang akhirnya mengurangi nafsu makan dan dapat mengganggu pertumbuhan tiram (Crassostrea sp). Salinitas 15 ppt tiram dapat hidup tetapi tidak mengalami pertumbuhan. Ini sesuai dengan pendapat Harramain (2005) tiram hidup pada salinitas yang tinggi, dan apabila salinitas sepanjang tahun stabil dengan lingkungan yang ideal, maka pertumbuhannya akan stabil pula.

Pertambahan lebar spesifik yang paling tinggi diperoleh pada tiram (Crassostrea sp) yang dipelihara dalam air dengan salinitas 30 ppt dibandingkan pada salinitas lainnya. Hal ini disebabkan karena kadar salinitas 30 ppt diduga tekanan osmotik lingkungan mendekati tekanan osmotik dalam tubuh tiram (Crassostrea $\mathrm{sp}$ ) sehingga konsentrasi ion relatif seimbang dan dalam pemanfaatan pakan sesuai dengan kebutuhannya. Ini sesuai pendapat Stickney dalam Anggoro et al. (2012), yang menyatakan bahwa tiram (Crassostrea $\mathrm{sp}$ ) yang dipelihara pada salinitas yang mendekati konsentrasi ion dalam darah, maka energi lebih banyak digunakan untuk pertumbuhan dan lebih sedikit untuk proses osmoregulasi. Salinitas diluar kisaran optimalnya aktivitas osmoregulasi meningkat sehingga jumlah energi yang dibutuhkan juga meningkat. Apabila energi untuk aktivitas osmoregulasi meningkat maka energi yang akan digunakan untuk pertumbuhan akan menurun sehingga mengakibatkan menurunnya laju pertumbuhan.

Menurut Affandi dan Riani (1994), menyatakan bahwa pada kondisi salinitas optimal penggunaan energi untuk osmoregulasi relatif lebih kecil dibandingkan dengan salinitas diluar optimal, dan pada salinitas optimal tersebut pertumbuhan mencapai maksimal. Oleh karena itu pada perlakuan D (salinitas $15 \mathrm{ppt}$ ) yaitu 0,039 mm, memiliki pertambahan lebar lebih rendah disebabkan kondisi salinitas yang kurang optimal.

Perlakuan A dengan salinitas 30 ppt memiliki nilai tertinggi terhadap pertambahan bobot tiram, ini disebabkan karena dengan salinitas $30 \mathrm{ppt}$ tekanan osmotik pada cairan dalam tubuh tiram (Crassostrea $\mathrm{sp}$ ) seimbang dengan media tempat hidupnya (isosmotik) sehingga energi yang dibutuhkan lebih kecil secara otomatis pemanfaatan pakan lebih optimal. Semakin kecil energi yang dikeluarkan maka semakin cepat pertumbuhannya. Sedangkan pada perlakuan D mengalami pertumbuhan yang lambat dari pada perlakuan yang lain, ini disebabkan karena salinitas yang rendah yaitu $15 \mathrm{ppt}$, dimana tekanan osmotik lingkungan perairan lebih rendah dibandingkan dengan tekanan osmotik cairan tubuh tiram, akibatnya tiram cenderung banyak mengeluarkan energi untuk proses osmoregulasi.

Ini sesuai dengan pendapat Gilles dan Pequeux (1983), yang menyatakan bahwa semakin jauh perbedaan tekanan osmotik tubuh dengan tekanan osmotik lingkungan, maka akan semakin banyak beban kerja energi metabolisme yang dibutuhkan untuk melakukan osmoregulasi sebagai upaya adaptasi pada lingkungan yang bersalinitas. Menurut Arisandi et al. (2011), menyatakan bahwa tiram (Crassostrea sp) akan mengalami pertumbuhan yang lambat apabila salinitas yang terlalu rendah atau terlalu tinggi dari kisaran salinitas yang sesuai dengan syarat hidupnya hingga jangka waktu tertentu. Perbedaan salinitas mempengaruhi mekanisme fisiologi dan biokimia, sebab proses perubahan tekanan osmosis berkaitan erat dengan peran membrane sel dalam proses transport nutrien. 


\subsubsection{Parameter kualitas air dan kehidupan tiram}

Suhu air selama penelitian yaitu $27,3-30,1^{\circ} \mathrm{C}$ masih layak untuk kehidupan tiram (Crassostrea sp). Menurut Utojo et al. (2005), suhu air yang optimal bagi kehidupan tiram yaitu 15-33 ${ }^{\circ} \mathrm{C}$, dibawah suhu $15{ }^{\circ} \mathrm{C}$ pertumbuhan tiram menjadi lambat karena tiram akan berhenti makan. Nilai pH sangat penting dalam budidaya tiram, sebab $\mathrm{pH}$ air merupakan faktor pembatas pada kehidupan tiram dan jasak renik lainnya. $\mathrm{pH}$ air yang baik untuk kehidupan tiram adalah netral sampai sedikit alkali 6-8, oksigen terlarut (DO) berkisar antara 3-6 ppm. Hal tersebut sesuai dengan kondisi $\mathrm{pH}$ air selama penelitian yaitu 7,2-7,8. Nilai oksigen terlarut dalam air media penelitian berkisar antara 4,6$6,0 \mathrm{ppm}$ masih dalam kisaran yang layak, karena dalam media penelitian diterapkan aerasi yang bertujuan untuk terjadinya proses difusi oksigen diperairan.

Kualitas air sangat berpengaruh terhadap pertumbuhan tiram ini disebabkan apabila terjadi perubahan maka memaksa bivalvia dalam adaptasi yang baru. Suhu memegang peranan penting dalam aktifitas biofisiologi tiram didalam air, seperti aktifitas filtrasi dan metabolisme. Perubahan $\mathrm{pH}$ diperairan dapat mempengaruhi fisiologi antara lain reproduksi, perkembangbiakan dan aktifitas dari tiram. Perubahan oksigen terlarut dalam perairan dapat mempengaruhi pernapasan, proses metabolisme atau pertukaran zat yang kemudian menghasilkan energi untuk pertumbuhan (Winanto, 2004).

\section{Kesimpulan}

Salinitas yang berbeda berpengaruh sangat nyata terhadap pertambahan panjang, lebar, dan pertambahan bobot, dan tidak berbeda nyata terhadap kelangsungan hidup. Pertambahan panjang, lebar dan bobot terbaik terdapat pada perlakuan A yang bersalinitas 30 ppt yaitu rata-rata pertambahan panjang sebesar 0,252 $\mathrm{mm}$, dan pertambahan lebar sebesar $0,144 \mathrm{~mm}$ sedangkan pertambahan bobot sebesar 1,104 gram. Rata-rata tingkat kelangsungan hidup untuk perlakuan $A$ yaitu $97 \%$, perlakuan B yaitu $93 \%$, perlakuan $C$ dan D yaitu $90 \%$. Ratarata kualitas air selama penelitian suhu $27,3-30,1{ }^{\circ} \mathrm{C}, \mathrm{pH} 7,2-7,8$ dan DO 4,6-6,0 ppm.

\section{Bibliografi}

Affandi dan Riani, 1994. Studi adaptasi benih ikan sidat (elver) Anguilla bicolor bicolor pada berbagai tingkat salinitas. Fakultas Perikanan - IPB. Bogor. 11 hal.

Anggoro, S., Diana R., Johannes, H., 2012. Pengaruh Salinitas Media Ynag Berbeda Terhadap Pertumbuhan Keong Macan (Babylonia spirata L) pada Proses Damestikasi. Jurusan Perikanan. Fakultas Perikanan dan Kelautan. Universitas Diponegoro. Semarang.

Arisandi, A., Marsoedi, Nursyam H., Aida, S., 2011. Pengaruh Salinitas Yang Berbeda Terhadap Morfologi Ukuran dan Jumlah Sel, Pertumbuhan Serta Rendaman Keragihan Kappaphycus alvarezi. Jurusan IKL FP Universitas Trunojoyo.

Castro, P., Huber M. E., 2007. Marine Biology, Sixth Edition. Published by McGraw-Hill.

Effendie, M.I., 1979. Metoda biologi perikanan. cetakan pertama. Penerbit Yayasan Dewi Sri. Fakultas Perikanan IPB. Bogor.
Gilles, R. and Pequeux, A., 1983. Interactions of Chemical and Osmotic Regulation with the Environment, p: $109-177$. In F. J. Vernberg and W.B. Vernberg, Eds. The Biology of Crustacea. Volume 8. Environmental Adaptasion. Academic Press, New York.

Gosling, E., 2003. Bivalve Molluscs. MPG Books Ltd, Great Britain.

Harramain., 2005. Kajian Faktor Lingkungan Habitat Kerang Mutiara (StadiaSpat) di Pulau Lombok, Nusa Tenggara Barat. 27 Agustus 2015. 6 hal.

Keenan, C.W., 1999. Kimia Untuk Universitas. Erlangga. Jakarta.

Sudradjat, A., 1982. Kemungkinan pengembangan budidaya tiram, crassostrea spp. Di Kepulauan Riau. Laporan Balai Penelitian Perikanan Laut.

Taufiq, N., Retno, H., Justin, C., Jussac, M.M., 2006. Pertumbuhan Tiram Mutiara (Pinctada maxima) Pada Kepadatan Berbeda. Jurusan Ilmu Kelautan. Universitas Diponegoro. Semarang.

Utojo, Mansyur, A., Taranamulia, Pantjara, Hasnawai, B., 2005. Identifikasi Kelayakan Lokasi Budidaya Laut di Perairan Teluk Kupang, Nusa Tenggara Timur. Journal Penelitian Perikanan Indonesia.

Winanto, T., 2004. Memproduksi Benih Tiram Mutiara. Jakarta: Penebar Swadaya.

Yitnosumarto, S., 1990. Dasar-dasar Statistika. PT Raja Grafindo Persada. Jakarta. 